\title{
ReVising Assisted OUTPATIENT Treatment StatuTeS in Indiana: Providing Mental Health Treatment FOR THOSE IN NEED
}

\author{
Katherine B. Cook ${ }^{*}$
}

I. INTRODUCTION 662

A. The Issue 663

B. Roadmap 665

II. WHY AOT STATUTES ARE NECESSARY 666

A. Who Is Affected? 666

B. Why Severely Mentally Ill Individuals are More Susceptible to Being Incapable of Understanding That They Need Treatment; Lack of Insight

C. Reports Show That Medication or Other Treatment Can Help668 1. The Revolving Door of Severely Mentally Ill Individuals . 668

a. Violence 669

b. Homelessness 671

c. Recidivism and other problems in jails or prisons and in hospitalization.

(I) Jails are inappropriate for seriously mentally ill individuals.

(II) Prison is not the right place for many seriously mentally ill individuals

3. Higher Costs for Inmates in Jails and Prisons..................675

D. Evolution from Civil Commitment Statutes.............................676

E. Who These Civil Commitment Statutes Fail to Protect............6 676

III. MODEL STATUTES/KENDRA's LAW ............................................6.677

A. Kendra's Law: the Most Prominent AOT Statute .................... 677

1. Weaknesses of the Statute..............................................679

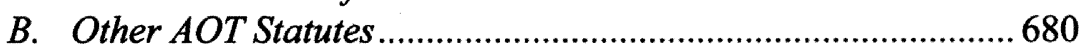

C. Results of AOT Statutes/Studies ...........................................681

D. Argument against AOT Statutes: Constitutionality.................683

IV. INDIANA's AOT STATUTE ..........................................................68 684

A. Indiana Statute .....................................................................684

B. Weaknesses of Indiana's Statute ...........................................684

1. Dangerous or Gravely Disabled ....................................685

2. No Standard of Proof .......................................................685

3. Lack of 3rd Party Petition Ability ...................................686

4. No Mandated Time Commitment.....................................686

5. No Definitions for the Terms ..........................................686

* J.D., 2012, Indiana University Robert H. McKinney School of Law; B.A., 2003, University of Wisconsin-Madison. 
6. No Guarantees of Outpatient Program Placement 687

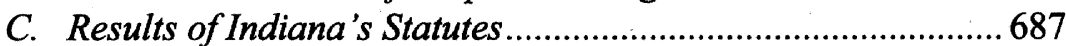

V. REVISED AOT STATUTE PROPOSAL FOR INDIANA ...........................688

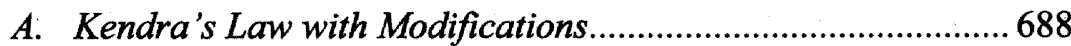

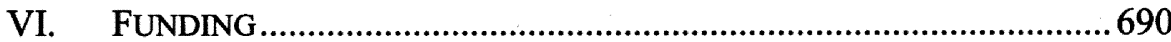

A. Benefits of AOT: Reduction in Hospital Costs.........................691

B. Funding Through Medicaid or Taxes .............................................. 691

VII. CONCLUSION

692

\section{INTRODUCTION}

"Tragedies make headlines. Too often, these tragedies involve victims or perpetrators with severe mental illness and could have been prevented if only there had been timely treatment." On January 8,2011 , six people were killed, and twelve more were seriously injured, including gravely wounded former Congresswoman Gabrielle Giffords, when an armed assailant open-fired on a crowd gathered for a political rally at a supermarket parking lot in Arizona. ${ }^{2}$ Two medical experts concluded that Jared Loughner, the alleged shooter in the case, suffers from schizophrenia, disordered thinking, and delusions, including delusional ideas regarding Rep. Giffords. $\mathrm{He}$ is currently adjudged unfit for trial and is undergoing forced medication and mental health treatment at a federal prison hospital in Missouri. ${ }^{3} \mathrm{Be}-$ fore the shooting, Loughner exhibited signs that he had a serious mental illness, yet these signs were not taken seriously. ${ }^{4}$ It is possible that mental health treatment may have prevented this horrific event that ruined not only the lives of the victims and their families, but also Loughner's life. ${ }^{5}$

Signs of mental instability were observed before the shootings. First, in October 2007, Loughner was cited for possession of drug paraphernalia. ${ }^{6}$ Although the charge was later dismissed, Loughner was required to com-

1. Mental Illness in 2010: Top Under-Reported Stories, TrEatMENT AdVocaCY CTR., http://www.treatmentadvocacycenter.org/index.php?option=com_content\&task=view \&id=171 1 \&Itemid=247 (last visited Mar. 26, 2012).

2. E. Fuller Torrey, A Predictable Tragedy in Arizona, We Emptied State Mental Hospitals Starting in the 1960s without Providing Adequate Treatment Alternatives, WALL ST. J. (Jan. 12, 2011), http://online.wsj.com/article/SB100014240527487037797045760739 73345594508.html.

3. Id.; Joseph Schuman, Jared Lee Loughner Trial: Judge Grants Doctors More Time To Restore Accused's Mental Fitness, Huffington Post, Feb. 6, 2012, http://www. huffingtonpost.com/2012/02/06/jared-lee-loughner-trial-mental-

competency_n_1258397.html.

4. Torrey, supra note 2 ("The fact that he was barred from his college until he was evaluated by a psychiatrist would appear to confirm the nature of the problem.").

5. See generally Jared Loughner Had 5 Run-ins with College Police, CBSNEWS.COM (Jan. 10, 2011, 4:42 PM), http://www.cbsnews.com/stories/2011/01/10/national/main72 31560.shtml.

6. Id. 
plete a pretrial diversion program. ${ }^{7}$ Also, on October 4, 2011, Loughner was suspended from Pima Community College and that same week withdrew from the college. ${ }^{8}$ On October 7, 2011, Loughner received a letter from the college informing him that in order to be readmitted he would have to provide the college with a letter from a mental health official indicating "his presence at the college does not present a danger to himself or others." Thus, prior to the shooting, Loughner was already in the criminal justice system and was showing obvious symptoms of a serious mental illness.

The glaring problem is that Arizona's public mental-health services are inadequate. ${ }^{10}$ Per capita, Arizona offers less community health services and maintains less psychiatric beds than forty-eight states; however other states, such as Indiana, are not much better equipped with those services. ${ }^{11}$ "If you don't have hospital beds and outpatient clinics to treat mentally ill people, those people don't get treated."12 The tragedy caused by Jared Loughner was just waiting to happen. ${ }^{13}$ While Arizona has less psychiatric bed and community treatment availability than most states, at present, no state in the nation has enough beds for its mentally ill population. ${ }^{14}$ The current tragedy happened in Arizona, but the same situation could have easily occurred in any other state. "The killing of six people in Tucson is one more sad episode in an ongoing series of tragedies that should not be happening." 16 The solution is clear-ensure, through outpatient treatment, that people who have a severe mental illness receive the care they need. ${ }^{17}$

\section{A. The Issue}

"A 2008 study out of the University of Pennsylvania that examined murders committed in Indiana between 1990 and 2002 found that approximately $10 \%$ of the murders were committed by individuals with serious

7. Id.

8. Id.

9. Id.

10. Torrey, supra note 2 .

11. Id.

12. Id.

13. Id.

14. $I d$.

15. Id.

16. Id.

17. Id. ("Based on Arizona's 2010 population and on estimates by the National Institute of Mental Health of the number of individuals with untreated schizophrenia at any given time, there are today in Arizona over 21,000 individuals with untreated schizophrenia. Most of them, thankfully, are not violent. But a small number of them-about $10 \%$ according to my meta-analysis of relevant studies-do become violent, usually because of their delusional thoughts and what their voices (auditory hallucinations) are telling them. This situation holds in every state. It is thus not a question of if such tragedies will occur but rather when and how often."). 
mental illnesses."18 "At least $40 \%$ of the 3.5 million Americans diagnosed with either schizophrenia or manic-depression" (both severe mental illnesses) "lack insight into their disorder; and they do not recognize that the symptoms of their mental illnesses are, in fact, symptoms." ${ }^{19}$ They are "unaware that they are ill" and do not, or cannot, seek the treatment they need. $^{20}$

One key to correct this startling situation is assisted outpatient treatment ("AOT"):

AOT is court-ordered treatment (including medication) for individuals who have a history of medication noncompliance, as a condition of remaining in the community. Studies and data from states using AOT prove that it is effective in reducing the incidence and duration of hospitalization, homelessness, arrests and incarcerations, victimization, and violent episodes. AOT also increases treatment compliance and promotes long-term voluntary compliance, while reducing caregiver stress.",21

AOT statutes have been enacted in many states, and have proven helpful not only for individuals but for society as a whole, by reducing recidivism, homelessness, and violence; and by improving overall quality of life. ${ }^{22}$ While the debate over whether these statutes are constitutional persists, states have upheld the statutes against due process challenges. ${ }^{23}$ It also appears that the Supreme Court would apply an intermediate scrutiny standard, if not simply rational basis, and uphold these statutes as a legitimate state interest. ${ }^{24}$

Indiana has a series of statutes giving the court authority to order as-

18. Id.

19. Kathleen Winchell, The Need to Close Kentucky's Revolving Door: Proposal for a Movement Towards a Socially Responsible Approach to Treatment and Commitment of the Mentally Ill, 29 N. KY. L. REV. 189, 189 (2002).

20. See William Spaulding, Applications of Therapeutic Jurisprudence in Rehabilitation for People with Severe and Disabling Mental Illness, 17 T.M. COOLEY L. REV. 135, 135 (2000).

21. Assisted Outpatient Treatment Laws, Treatment ADVOCACY CTR., http://www. treatmentadvoca-

cycenter.org/index.php?option=com_content $\&$ task=view $\& i d=39 \&$ Itemid $=68$ (last visited Mar. 26, 2012).

22. See New York State Assisted Outpatient Treatment Program Evaluation, N.Y. State OfFice of Mental Health (June 30, 2009), http://www.omh.ny.gov/omhweb /resources/publications/aot_program_evaluation/.

23. In re K.L., 806 N.E.2d 480, 485-86 (N.Y. 2004); see also Riggins v. Nevada, 504 U.S. 127, 136 (1992).

24. In re K.L., 806 N.E.2d at 485; see Washington v. Harper, 494 U.S. 210, 222-23, 229 (1990) (prison); Mills v. Rogers, 457 U.S. 291, 299 (1982) (hospitalization). 
sisted outpatient treatment, but they are lumped in with the inpatient commitment statutes and do not differentiate between the two types of treatment or give different elements to satisfy each. ${ }^{25}$ The current legislation is ineffective and rarely used by courts for the purpose it was created. ${ }^{26}$ While there is a statute allowing for AOT on a voluntary basis, known as the Psychiatric Assertive Identification and Referral (PAIR) program, it is voluntary and only helps a comparatively small percentage of people: those who choose to go through the program instead of jail. ${ }^{27}$ The PAIR program does not address other individuals with serious mental illnesses who also need treatment, such as the homeless; those who are recently released from prison; and those who do not belong in jail but would not voluntarily choose to go through PAIR. ${ }^{28}$ An amendment to the statute is in order so as to improve the lives not only of the individuals, but of others in the community and society as a whole.

\section{B. Roadmap}

Section II of this Note will discuss why AOT statutes are necessary. It will give a brief background of the persons that AOT statutes affect, as well as the types of mental illnesses that are specifically addressed. Section II will also examine the reasoning behind the necessity of AOT statutes and whether medication or other treatment has been proven to be helpful in certain types of behaviors. Section III will discuss statutes in other states that have proven to be effective, as well as their weaknesses. In Section III, several well-known case studies will also be analyzed to measure AOT effectiveness. Section IV discusses the current state of Indiana's AOT law and its weaknesses. Section $\mathrm{V}$ proposes a new Indiana statute that more specifically defines assisted outpatient treatment rules and implementation in Indiana and briefly touches on the constitutionality of AOT statutes. Finally, Section VI lays out possible funding options.

25. See IND. CoDE $\S \S 12-26-14-1$ to -5 (2010).

26. Abby Flynn \& Rosanna Esposito, Indiana Needs to Use Assisted Outpatient Treatment (AOT) and Stop Criminalizing Mental Illness, in MICHAEL W. KEMPF, MENTAL ILLNESS AND THE CRIMINAL JUSTICE SYSTEM IN INDIANA 17 (2008), available at http://www.nami.org/Content/Microsites169/NAMI_Indiana/Home156/Resources87/Kempf _Report_6_13_2008.pdf.

27. George F. Parker, M.D., Dir. of Forensic Psychiatry, Ind. Univ. Sch. of Med., Lecture at Ind. Univ. Robert H. McKinney Sch. of Law: Mental Illness and the Criminal Justice Sys. (Feb. 24, 2011).

28. Judge Barbara A. Collins, Mental Health Ct., Lecture at Ind. Univ. Robert H. McKinney Sch. of Law: Mental Illness and the Criminal Justice Sys. (Feb. 24, 2011). 


\section{WHY AOT STATUTES ARE NECESSARY}

\section{A. Who Is Affected?}

This article will address AOT statutes that only affect the severely mentally ill with psychotic symptoms. In some states, AOT statutes are used on a variety of mentally ill individuals, including those who do not fall into the severe category. ${ }^{29}$ Many mental health groups use the phrase "severe and persistent mental illness" to identify individuals who suffer from a DSM- IV Axis I disorder. ${ }^{30}$ Axis I disorders include schizophrenia, schizoaffective disorder, bipolar disorder, and major depression. ${ }^{31}$ Axis I psychotic disorders like schizophrenia include three types of symptoms: (1) positive symptoms, which distort reality for the individual and include hallucinations, delusions, and paranoia; (2) negative symptoms, which often lead to a decline in emotional functioning, such as sadness; and (3) cognitive symptoms, which may affect memory and attention. ${ }^{32}$ The positive/psychotic symptoms (i.e., hallucinations and delusions) are a primary source of problems associated with homelessness, violence, and arrests and are most commonly found in people with the Axis I disorder of schizophrenia. ${ }^{33}$ Research suggests that persons with schizophrenia, for example, are "meaningfully impaired in real-world tasks that involve shifting attention in cluttered scenes." 34 Thus, they are less likely to be able to function in the same way that many others do.

\section{B. Why Severely Mentally Ill Individuals are More Susceptible to Being}

Incapable of Understanding That They Need Treatment; Lack of Insight

Another symptom of psychotic illnesses is lack of insight. Between

29. See Rachel A. Scherer, Note, Toward A Twenty-First Century Civil Commitment Statute: A Legal, Medical, and Policy Analysis of Preventive Outpatient Treatment, 4 IND. HEALTH L. REV. 361, 369-70 (2007).

30. Id. at $371-72$.

31. George F. Parker, M.D., Dir. of Forensic Psychiatry, Ind. Univ. Sch. of Med., Lecture at Ind. Univ. Robert H. McKinney Sch. of Law: Introduction to Severe Mental Illness (Jan. 20, 2011); see also AM. PSYChIATRIC Ass'N, QUiCK REFERENCE to the DiagnOstiC CRITERIA FROM DSM-IV-TR, at xi, 37-38 (2000) (describing inherent limitations to diagnostic categorizations, explaining the multiaxial system).

32. L.M. Camargo et al., Disrupted in Schizophrenia 1 Interactome: Evidence for the Close Connectivity of Risk Genes and a Potential Synaptic Basis for Schizophrenia, 12 MOLECULAR PSYCHIATRY 74, 74 (2007); Scherer, supra note 29, at 372.

33. Paul S. Appelbaum et al., Violence and Delusions: Data from the MacArthur Violence Risk Assessment Study, 157 AM. J. PsYchIATRY 566 (2000); see also Scherer, supra note 29 , at $416-17$.

34. Rebecca L. Fuller et al., Impaired Control of Visual Attention in Schizophrenia, 115 J. ABnormal Psychol. 266, 273 (2006); see also E. Fuller Torrey, SURVIVING SCHIZOPHRENIA: A MANUAL FOR FAMILIES, CONSUMERS, AND PROVIDERS 35 (5th ed. 2006) (1983). 
forty and sixty percent of those diagnosed with schizophrenia and manicdepressive illness may be truly unaware that they are ill and thus find no reason to take treatment. ${ }^{35}$ This lack of insight into one's own illness is a biological symptom known as anosognosia. ${ }^{36}$ This symptom is especially difficult to overcome when untreated because the more someone, even a trusted loved one, tries to convince the mentally ill individual that he/she is suffering from a hallucination or delusion, the more the individual may believe the hallucination or delusion to be true, and the loved one to be lying. ${ }^{37}$ Ultimately, such individuals may sink further into their illness, as their belief in the reality of their symptoms is unshakeable. Someone suffering from such a symptom is likely to reason, "Why should I take medication if there is nothing wrong with me?",38

Distorted reality may also influence whether mentally ill individuals continue with treatment. Half of all schizophrenics stop using their medications within one year of beginning treatment. ${ }^{39}$ One common reason for this is adverse side effects, ${ }^{40}$ but these are becoming less and less of an issue with advancements in medicine. ${ }^{41}$ Another reason is because of the distorted reality. "[A] '[schizophrenic's] distorted view of reality [may] not allow [him or her] to recognize [his or her] illness,' and as such, [he or she] terminate[s] the medication." 42 The nature of a schizophrenic person's delusions make him prone to "abandon the [highly effective] medications that may quell the angry, suspicious voices in [his] head[]." ${ }^{43}$ If patients do not believe they are mentally ill and in need of medication, or if they do not believe medication will help them, they will not follow through with community treatment when left unmonitored. ${ }^{44}$

35. E. Fuller Torrey \& Mary T. Zdanowicz, Introduction in TREATMENT ADVOCACY CTR., MODEL LAW FOR ASSISTED TREATMENT (2000), available at http://www.treatment advoca-

cycenter.org/GeneralResources/index.php?option $=$ com_content\&task=view\&id=49\&Itemid $=78$; Xavier F. Amador et al., Awareness of Illness in Schizophrenia and Schizoaffective and Mood Disorders, 51 ARCHIVES GEN. PSYCHIATRY 826, 828-29 (1994) ("'finding that nearly sixty percent of patients with schizophrenia had moderate to severe unawareness of having a mental disorder"').

36. Torrey \& Zdanowicz, supra note 35.

37. Parker, supra note 31.

38. Torrey \& Zdanowicz, supra note 35.

39. Elana H. Margolis, The Failure of Civil Confinement: How Russell E. Weston Jr. Slipped Through the Cracks and the Potential for Many More to Follow, 26 NEw ENG. J. CRIM. \& CIV. CONFINEMENT 129, 133 (2000).

40. See Theodore Van Putten, Why Do Schizophrenic Patients Refuse to Take Their Drugs?, 31 ARCHIVES OF GEN. PsYCHIATRY 67, 70 (1974).

41. Torrey \& Zdanowicz, supra note 35.

42. See Margolis, supra note 39, at 133 (quoting Schizophrenics Often Quit Taking Medicine, NEWS \& REC. (Greensboro, N.C.), July 28, 1998, at A4).

43. Id. (internal quotation marks omitted).

44. See id. 


\section{Reports Show That Medication or Other Treatment Can Help}

Treatment is essential to help control symptoms of mental illness, especially if found early on, such as when the first hospitalizations or arrests occur. $^{45}$ Medication, while the most effective treatment for schizophrenia, is not the only treatment that is often used. ${ }^{46}$ Psychotherapy, cognitive behavioral therapy, housing assistance, vocational rehabilitation, and other community services are good supplements to enhance the medication's effects and to help the individual achieve a higher recovery level. ${ }^{47}$ "Further, most of the antipsychotic medications used to treat schizophrenia only help to treat the positive symptoms and so medication should be supplemented with other forms of treatment to help cope with the negative and cognitive symptoms of the disease." 48

\section{The Revolving Door of Severely Mentally Ill Individuals}

Non-adherence to medication leads to what is known as the "revolving door." 49 This phenomenon describes the process by which an individual with a severe mental illness commits a crime (or becomes hospitalized), and for a variety of reasons is released back onto the streets without support or supervision and then commits another crime. ${ }^{50}$ The individual may have been released because she was found incompetent to stand trial but did not fit the high standards for inpatient civil commitment, or she may have been released from the hospital after she was stabilized on her medications, but she stopped taking them upon her release. 51 This is extremely common, and some individuals with severe mental illnesses are arrested multiple times per year. ${ }^{52}$ Without a mechanism that ensures individuals are compliant with their medications once they are released, the cycle will continue.

Compared to other states, Indiana has more laws that address this "revolving door" issue, but only after the individual with the serious mental

45. Nat'l Alliance on Mental Illness Ind., Public Policy Platform 1, available at http://www.nami.org/Content/Microsites169/NAMI_Indiana/Home156/Advocacy21/ Platform\%20final\%20joes.pdf ("Early identification and treatment accelerates recovery and protects the brain from further harm related to the course of the illness . . . Most people with serious mental illness need medication to help control symptoms.").

46. See id. ("Most people with serious mental illness . . . also rely on supportive counseling, self-help groups, assistance with housing, vocational rehabilitation, income assistance, and other community services.").

47. Scherer, supra note 29 , at 379-80.

48. Id. at $379-80$.

49. See generally Winchell, supra note 19.

50. Collins, supra note 28.

51. See Winchell, supra note 19 , at 190.

52. Id. (chronicling the legal and mental health history of Patricia Ann Smith, a thirtyeight-year-old Louisville woman, who had been diagnosed with schizophrenia, and who has been arrested at least sixty times in the past seven years (citing Kim Wessel, Arrests of Mentally Ill Woman Continue, COURIER J., June 22, 2001, at A1)). 
illness is identified by police. If he or she meets certain criteria, the mentally ill offender may elect to participate in the PAIR program. ${ }^{53}$ In this program, a mentally ill offender completes an assigned outpatient treatment program in lieu of going to jail. ${ }^{54} \mathrm{He}$ must plead guilty to participate in the program, and after one year's successful completion, his charge will be dismissed. $^{55}$

While this program is an essential tool in diverting seriously mentally ill individuals from getting stuck in the revolving door, it only focuses on a sub-section of the population who could greatly benefit from AOT. Specifically, it fails to include those who elect not to participate in the program, often as a result of the symptoms of their mental illness, and on people who desperately need treatment but have not been arrested. Additionally, AOT statutes should include those mentally ill individuals who have been recently released from jail or prison and are in need of AOT to re-integrate them into society or to help them continue with their medication without a lapse in treatment. Therefore, mandatory AOT statutes for certain qualified individuals would complement and extend the results achieved through the PAIR program by including these additional populations within their scope.

\section{a. Violence}

One reason supporting the need for mandatory AOT statutes is the violence associated with the psychotic symptoms of certain severe mental illness, which is exacerbated by non-adherence to medication. Some studies have shown that an increased level of psychotic symptoms may be the best predictor of the likelihood of committing a violent act. ${ }^{56}$ Other studies suggest that another important predictor of future violence among the severely mentally ill is non-adherence to medication. ${ }^{57}$ This non-adherence to medication is brought on, in part, by great difficulty in being able to meet the inpatient civil commitment standards (where a patient is forced to comply with medication regimes), and even if they originally meet these strict standards, by what typically happens after a patient is released from the hospital (where compliance is no longer required). "People with paranoid and psychotic symptoms, which can become worse if medications are discontinued, may [] be at higher risk for violent behavior." ${ }^{, 58}$ Dr. Torrey estimates there to be "approximately 1000 homicides a year" committed by

53. Collins, supra note 28.

54. Id.

55. Id.

56. E. Fuller Torrey, Out of The Shadows: Confronting America's Mental ILLNESS CRISIS 46 (1997).

57. $I d$.

58. Schizophrenia and Poverty, Crime and Violence, SCHIZOPHRENIA.COM, http://www.schizophrenia.com/poverty.htm\#society (last visited Apr. 11, 2012). 
people suffering from schizophrenia and bipolar disorder, "almost all of whom were not taking medication at the time of the homicide." 59

In 1992, sociologist Henry Steadman studied individuals discharged from psychiatric hospitals and found that of those stopping their medication, " 27 percent of . . . patients report at least one violent act within a mean of four months after discharge." ${ }^{, 60}$ Another study found that patients with a severe mental illness were twice as likely to commit an act of violence before hospitalization, when they were not on any medication, as compared to post-hospitalization, when they were taking medication. ${ }^{61}$. Further, though less than $1 \%$ of the total population compromise people with untreated severe mental illness, they are responsible for nearly 1000 homicides annually in the United States, or approximately 4 to $5 \%$ of all murders. ${ }^{62}$

Notably, other "research suggests that those with serious mental illnesses are no more dangerous than the general public when they take their prescribed medications." ${ }^{.63}$ Without any system of mandatory treatment in place, there are no assurances that individuals will remain compliant with their medication regimen upon release from jail or hospitalization. ${ }^{64}$

[I] $f$ the public ever becomes fully aware of how often mentally ill individuals with a history of violent behavior are released from jails and hospitals with no mandatory continuing treatment, there will be a mass outcry directed toward the lawyers, judges and psychiatrists who are responsible for this state of affairs. ${ }^{65}$

However, this outcry can easily be assuaged. Research suggests that patients who have a propensity for violence but are given mandatory AOT are "four times less likely ... to perpetrate serious violence after undergo-

59. Id.

60. Winchell, supra note 19, at 210 (quoting E. Fuller Torrey \& Robert J. Kaplan, $A$ National Survey of the Use of Outpatient Commitment, 46 PSYCHIATRIC SERVICES 778, 778 (1995)); see also Ken Kress, An Argument for Assisted Outpatient Treatment for Persons with Mental Illness Illustrated with Reference to a Proposed Statute for Iowa, 85 IowA L. REV. 1269, 1341-42 (2000).

61. Winchell, supra note 19 , at 210-11.

62. Id. at 211.

63. Christian E. Piccolo, Note, Falling Through the Cracks: The Need for Enhanced Supervision in the Involuntary Outpatient Civil Commitment Setting, 54 VILL. L. REV. 309, 318-19 (2009).

64. Fuller TORRey, Nowhere To Go: The Tragic OdysSey of the Homeless MENTALLY Ill 16 (1988).

65. Bruce G. Link \& Ann Stueve, Psychotic Symptoms and the Violent Behavior of Mental Patients Compared to Community Controls, in JoHN MONAHAN \& HeNRY J. Steadman, Violence and Mental Disorder: Developments in Risk Assessment 139 (1994). 
ing treatment." 66

\section{b. Homelessness}

Another reason in support of mandatory AOT statutes is the impact of homelessness on individuals with severe mental illness. "At any given time, there are more people with untreated severe psychiatric illnesses living on America's streets than are receiving care in hospitals."67 Approximately one-third of the homeless population ${ }^{68}$ is suffering from schizophrenia or bipolar disorder. 69 "People with serious mental illnesses have greater difficulty escaping homelessness than other people; many have been living on the streets for years."70 The majority of these mentally ill homeless individuals who are left on the streets without treatment "regularly forage through garbage cans and dumpsters" for any small amount of food in order to survive. ${ }^{71}$ Additionally, at least one-third of the homeless women who are mentally ill have been sexually assaulted, many on multiple occasions. $^{72}$ While many of these individuals would like to get off the street and undergo treatment, their mental illnesses blocks them from making that decision for themselves. ${ }^{73}$ When patients fail to seek treatment, the symptoms of their mental illnesses can easily take over.

\section{c. Recidivism and other problems in jails or prisons and in hospitali-} zation

The first reason that jails and prisons are not appropriate for the mentally ill is that jails and prisons are not structurally equipped to meet the needs of individuals with a serious mental illness. ${ }^{74}$ Secondly, the staff

66. Press Release, Columbia University, Outpatient Care for Individuals with Severe Mental Illnesses Reduces Crime, Say Researchers (Feb. 18, 2010), http://www.treatment advocacycenter.org/index.php?option=com_content\&task=view\&id=1511\&Itemid=247.

67. SCHIZOPHRENIA.COM, supra note $\overline{58}$.

68. $I d$.

69. Id. (indicating approximately one third of the homeless population is mentally ill).

70. HUMAN RIGHTS WATCH, ILL-EQUIPPED: U.S. PRISONS AND OFFENDERS WITH MENTAL ILLNESS 21 (2003), available at http://www.hrw.org/sites/default/files/reports/ usa1003.pdf.

71. Treatment Advocacy CTR., Homelessness: One of the Consequences of Failing to TREat Individuals with SEVERE Psychiatric Disorders 4, available at www.treatmentadvocacycenter.org/storage/documents/homelessness--apr_09.pdf; Parker, supra note 27.

72. Torrey \& Zdanowicz, supra note 35 .

73. Schizophrenia and Homelessness: Our Demand for Efficiency Will Turn the Hardest Hit into Outcasts, PrelaPSE MAG., Sept. 1995, available at http://www.mental health.com/mag1/pre-hom1.html.

74. Schizophrenia and Poverty, Crime and Violence, SCHIzOPHRENIA.COM, http://www.schizophrenia.com/poverty.htm\#society (last visited Apr. 11, 2012). 
working at the facilities are not trained to act as psychiatric caretakers. ${ }^{75}$ Not surprisingly, incarcerating such large numbers of seriously mentally ill people creates additional problems. ${ }^{76}$ One such problem is the lack of psychiatric care subsequent to release from jail or prison because the corrections systems are separate from the mental health system. ${ }^{77}$ Consequently, recidivism is higher among seriously mentally ill individuals than it is for others who are released. ${ }^{78}$ In Los Angeles, ninety percent of the mentally ill inmates in the jail have been arrested at least once before. ${ }^{79}$ "Houston's Harris County Jail in 2008 included two mentally ill individuals who had been booked thirty times since 1999 and forty-five times since 2001. ${ }^{, 80}$ In Indianapolis, one seriously mentally ill homeless individual has been arrested eighty-three times in the course of three years, for small misdemeanors associated with living on streets. ${ }^{81}$ Two other individuals have been arrested thirty-four times each over the course of just one year. ${ }^{82}$

Moreover, "[p]ersons with mental illness who have prior criminal records or histories of violence have a particularly difficult time getting access to treatment; many mental health programs simply will not take them." 83 Thus, a system of guaranteed treatment through AOT will be able to provide them with the medical attention they need.

\section{(I) Jails are inappropriate for seriously mentally ill individuals}

Mentally ill individuals who commit a crime for reasons unrelated to the symptoms of their mental illness should be held accountable for the crime, like anyone else in society. ${ }^{84}$ However, seriously mentally ill people should neither be arrested nor imprisoned solely because they lack treatment or access to appropriate care, nor should they be incarcerated any longer than others would be simply because they are mentally ill. ${ }^{85} \mathrm{Be}-$ tween 2004 and 2005, there were over "three times more seriously mentally

75. E. Fuller Torrey et al., More Mentally Ill Persons are IN Jails and Prisons Than Hospitals: A SURVEY OF THE STATES 8-9 (2010), available at $\mathrm{http} / / / \mathrm{www}$. treatmentadvocacycenter.org/storage/documents/final_jails_v_hospitals_study.p df., at 8-9.

76. Id.

77. Id.

78. Id.

79. Id.

80. TORREY ET AL., supra note 75 , at 8-9.

81. Robert Hipple, Indianapolis Police Sergeant, Lecture at Indiana Univ. Robert H. McKinney Sch. of Law: Mental Illness and the Criminal Justice System (Feb. 24, 2011) (on file with author).

82. Id.

83. HUMAN Rights WaTCH, supra note 70, at 30.

84. Mark R. Munetz \& Patricia A. Griffin, Use of the Sequential Intercept Model as an Approach to Decriminalization of People with Serious Mental Illness, 57 PsYCHIATRIC SERVS. 544, 544 (2006).

85. Id. 
ill individuals in jails and prisons than in hospitals" in the United States. ${ }^{86}$ In 1991, the National Alliance for the Mentally Ill (NAMI), an advocacy group for the families of those with mental illnesses, surveyed 1401 members and found that $40 \%$ of the family members with serious mental illnesses of those in the group had been in jail at some point in their lives. "77 "The vast majority of people with schizophrenia who are in jail have been charged with misdemeanors such as trespassing. As many as one in five (20\%) of the 2.1 million Americans in jail and prison are seriously mentally ill." ${ }^{\text {" Th }}$ is includes inmates with schizophrenia, manic depression (bipolar disorder) and major depression. ${ }^{89}$

Many people suffering from schizophrenia are stuck in the revolving door between hospitals, jails and shelters. ${ }^{90}$ Thirty percent of those discharged from Illinois psychiatric hospitals return to the hospital within thirty days of their discharge. ${ }^{91}$ The percentage of re-hospitalizations substantially increases as time passes, with as much as a sixty percent rehospitalization rate within a year of discharge in New York. ${ }^{92}$

Suicide is another major problem in jails for the mentally ill. 93 "Suicide is the leading cause of death in jails and $95 \%$ of those who commit suicide in jails have psychiatric illnesses." showing that nearly half of all inmate suicides are committed by those who are mentally ill. ${ }^{95}$ One Washington study found that seventy-seven percent of those who attempted to commit suicide were mentally ill, as compared to fifteen percent among inmates in the general jail population. ${ }^{96}$

\section{individuals}

(II) Prison is not the right place for many seriously mentally ill

Unfortunately, in Indiana, the number of mentally ill being sent to prisons that are unable to provide the necessary treatment continues to increase. $^{97}$ Such confinement in the prison system, particularly within the

86. TORREY ET AL., supra note 75 , at 1 .

87. Id. at 9. at 25).

88. SCHIZOPHRENIA.COM, supra note 74 (citing HUMAN RIGHTS WATCH, supra note 70,

89. Id.

90. Id.

91. Id.

92. Id.

93. TORREY ET AL., supra note 75, at 9-11.

94. Torrey \& Zdanowicz, supra note 35 .

95. TORREY ET AL., supra note 75, at 9-11.

96. Id.

97. Human Rights Watch, Cold Storage: SuPER-MaXimum Security CONFINEMENT IN INDIANA 11 (1997), available at http://www.hrw.org/legacy/reports/1997/ usind/. 
higher security facilities, is reprehensible. ${ }^{98}$ People with mental illness have a very difficult time following the rules that govern society, and this difficulty is especially magnified in prison settings because prison rules are very restrictive. ${ }^{99}$ The consequences of not following prison rules cause intense stress. ${ }^{100}$ Many mentally ill prisoners are remanded to higher security facilities, even super-maximum security facilities, often due to the disciplinary records they have accumulated from being disruptive or not precisely following the rules due to lack of treatment.

In a recent interview at the New Castle Correctional Facility, an Indiana maximum-security prison, an inmate confided that he had been incarcerated for stealing a radio approximately twenty-six years ago. ${ }^{102} \mathrm{He}$ has schizophrenia, is not receiving the proper medication through the prison system, and has been continually detained because of his inability to control his psychotic symptoms. ${ }^{103}$ His psychotic episodes have included throwing excrement or committing other minor infractions. ${ }^{104}$ These rule infractions have resulted in his receiving an ever-increasing sentence, and the date of his release still unknown. ${ }^{105}$ Without proper treatment, his rule infractions could keep him incarcerated indefinitely, which is not an uncommon story.

Before the super-maximum security unit (SHU) in the Wabash Valley Correctional Facility was shut down for being inhumane because of its cruel and unusual punishments toward mentally ill prisoners, over half of the inmates sent to the facility were mentally ill. ${ }^{106}$ They were often sent there for numerous rule infractions in their former prisons. ${ }^{107}$ For these inmates, this real-life horror and unending cycle of "the social isolation and restricted activities aggravate their illness and immeasurably increase their pain and suffering. In a tragic vicious cycle, their worsened mental condition leads to more rule infractions, such as self-mutilation, for which they receive the additional punishment of even more time in segregation."108

Warehousing psychotic and severely ill people without access to appropriate treatment to curb their symptoms is a cruelty which no one deserves. $^{109}$ In some cases, it might even be considered torture. ${ }^{110}$ In 1997 , Edgar Hughes, an inmate in the supermax housing unit at Wabash Valley

98. Id.

99. Id.

100. Id.

101. Id.

102. Interview with anonymous source, Mental Health Unit at the New Castle Correctional Facility (Feb. 3, 2011).

103. Id.

104. Id.

105. Id.

106. HuMAN RighTS WATCH, supra note 97, at 11.

107. Id.

108. Id.

109. Id.

110. Id. at 11-12. 
Correctional Facility, ended his confinement in tragedy. ${ }^{111} \mathrm{He}$ was actively psychotic, extremely depressed, paranoid, and feeling persecuted by the guards. "112 He began "bombing" the guards with excrement and subsequently, one morning, he suffered a "mysterious head trauma," causing serious brain damage. ${ }^{13}$ Based on the facts available, Human Rights Watch concluded that "Hughes was the victim of one of two situations: either he suffered severe physical abuse at the hands of correctional officers, or he underwent a severe psychiatric breakdown in which he injured himself."114 Regardless of which of these possibilities occurred, Hughes's inappropriate confinement to this higher security facility resulted in an irreversible tragedy. 115

\section{Higher Costs for Inmates in Jails and Prisons}

Aside from the extremely high intangible costs, such as injury, death, and the general low quality of life for individuals with severe mental illnesses caught up in this revolving door system, tangible cost is also a significant factor in assessing whether the Department of Corrections is the right place for some mentally ill individuals. Due to the need for increased staffing and individualized space, inmates who suffer from a mental illness are more costly than non-mentally ill inmates. ${ }^{116}$ Mentally ill inmates stay in jail and prison longer. ${ }^{117}$ In one Florida jail, the average stay in jail for the general population is twenty-six days, versus fifty-one days for mentally ill inmates. ${ }^{18}$ In New York Riker's Island Jail, 42 days is the average time for all inmates, but for the mentally ill the average is 215 days. ${ }^{19}$ The longer stays are due to the difficulty that mentally inmates have with understanding and following the jail rules. 120

Seriously mentally ill individuals also present large management problems because of their impaired thinking. ${ }^{121}$ An audit of three Wisconsin state prisons in 2010 reported that "between 55 percent and 76 percent of inmates in segregation [isolation] are mentally ill."122 Moreover, these individuals are often abused because the correctional officers in jails and prisons are not trained to work with the seriously mental ill. ${ }^{123}$ The officers

111. Id. at 12.

112. Id.

113. $I d$.

114. Id.

115. Id. at 11-12.

116. TORREY ET AL., supra note 75 , at 9 .

117. Id. at 10.

118. Id.

119. Id.

120. Id.

121. Id.

122. Id. at 11.

123. Id. 
do not specifically apply to work with this subsection of the population, nor do they usually understand how to handle these individuals. ${ }^{24}$ AOT, however, helps alleviate the problem of these mentally ill individuals who do not belong in jail or prison through diversion to treatment instead.

\section{Evolution from Civil Commitment Statutes}

AOT statutes arose out of a growing need for a response or solution in lieu of the high standards that involuntary hospitalization (inpatient civil commitment) statutes maintain, and the lower costs of outpatient treatment. ${ }^{125}$ These inpatient civil commitment statutes, or "danger-or-gravedisability statutes," typically require a showing, by clear and convincing evidence, of an imminent risk of either a danger to oneself of others, or a grave disability. ${ }^{126}$ Such statutes exhibit major problems in execution, starting with the high level of proof required prior to such an order, clear and convincing evidence. ${ }^{127}$ The civil commitment statutes fail to protect both the safety of the mentally ill individual himself, and of the public. ${ }^{128}$

\section{E. Who These Civil Commitment Statutes Fail to Protect}

AOT statutes fail in part because:

Although a dangerous individual with mental illness may be involuntarily hospitalized, her commitment must be dismissed the minute she either ceases to suffer from mental illness or ceases to be dangerous. Many individuals with serious mental illness enter the hospital, frequently under court order, and remain hospitalized until they improve and no longer meet the standards for involuntary hospitalization . . . . Left to their own devices, consumers often relapse and be-

124. Id.

125. See Scherer, supra note 29 , at 415 .

126. Id. at 366, 433; see also TREATMENT AdvocaCy CTR., Assisted PSYChIATRIC TREATMENT: INPATIENT AND OUTPATIENT STANDARDS BY STATE (2011), available at http://www.treatmentadvocacycenter.org/storage/documents/new_the_updated_state_standar ds_chart.pdf (detailing the key language of each state's civil commitment statute; language concerning dangerousness or risk of harm or injury is present in each); IND. CODE § 12-7-253 (2006).

127. Scherer, supra note 29 , at 366.

128. Id. ("For many severely mentally ill persons, this standard is nearly impossible to prove in a court of law and resultantly fails to protect a significant population of severely mentally ill persons: those who are in need of treatment but are neither dangerous nor disabled to the extreme degree . . . . Further, the danger-or-grave-disability statutes . . . wait for moments of extreme deterioration to occur before permitting involuntary treatment, by which time it may be too late to effectively rehabilitate the individual."). 
come ill, dangerous, and in need of rehospitalization. ${ }^{129}$

Civil commitment statutes, as written, fail everyone. They provide little help to individuals who suffer from debilitating illnesses and do not deliver enough insight (or time to develop insight while in the hospital) to make decisions on their own treatment. They fail to protect individuals' family members who must watch them suffer and have no ability to stop their deterioration. The statutes also fail to protect society and the victims that are hurt because of patients' psychotic episodes. These failures can all be alleviated, however, through a court-mandated system of assisted outpatient treatment, whereby the individual will be monitored to ensure compliance with taking their medication or other forms of treatment.

\section{MODEL STATUTES/KENDRA'S LAW}

\section{A. Kendra's Law: the Most Prominent AOT Statute}

Kendra's Law is the New York assisted outpatient statute named after a specific victim, Kendra Webdale. Kendra was a young woman who was pushed off a subway platform in New York City by a man with paranoid schizophrenia, who had just been released from hospitalization after failing to meet the "dangerous" requirement of New York's civil commitment statute. ${ }^{130}$ According to the text of the statute, there are seven requirements that must be satisfied in order for a person to receive AOT: ${ }^{13}$

(1) He or she must be at least 18 years old. ${ }^{132}$

(2) The individual must be suffering from a mental illness, as determined by a mental health physician. ${ }^{133}$

(3) The individual must be "unlikely to survive safely in the community without supervision, based on a clinical determination,"134 i.e., can he live safely on his own? ${ }^{135}$ (4) The individual must have "a history of lack of compliance with treatment for mental illness." ${ }^{136}$ This can be shown in one of two ways: (a) either psychiatric hospitalization or psychiatric treatment in a correctional facility at least twice within the previous two years; or (b) at least

129. Kress, supra note 60, at $1295-96$.

130. Edie Magnus, A Deadly Encounter, MSNBC (Jan. 20, 2007, 3:46 PM), http://www.msnbc.msn.com/id/16713078 .

131. See Kendra's Law, N.Y. MeNTAL HYG. Law $\S 9.60$ (McKinney 2006).

132. Kendra's Law, N.Y. MENTAL HYG. LAW $\$ 9.60(c)(1)$ (McKinney 2006).

133. Id. § 9.60(c)(2).

134. Id. $\$ 9.60(\mathrm{c})(3)$.

135. See Scherer, supra note 29, at 387.

136. N.Y. MENTAL HYG. LAW $§ 9.60(c)(4)$ (McKinney 2006). 
one overt act, attempt, or threat of serious physical harm to self or others within the previous four years. ${ }^{137}$

(5) The statute says that, "as a result of his or her mental illness, [the individual is] unlikely to voluntarily participate in outpatient treatment that would enable him or her to live safely in the community,",138

(6) In light of the individual's history and current behavior, he or she is "in need of assisted outpatient treatment in order to prevent a relapse or deterioration which would be likely to result in serious harm to the person or others." 139

(7) Lastly, the individual must be "likely to benefit from assisted outpatient treatment."140

An additional provision notes that that the standard of proof for an individual to receive treatment under this statute is "clear and convincing evidence." 141 Another provision allows third-person parties, described in the statute, to bring a petition to the court for an individual to receive treatment. ${ }^{142}$ Persons deemed appropriate to bring the petition include those who reside with the individual (and are at least eighteen years old), firstdegree relatives, medical professionals and police officers who have had experience with the individual. ${ }^{143}$ The statute further defines what types of treatment shall be administered ${ }^{144}$ and provides that "treatment shall include case management services or assertive community treatment team services to provide care coordination." 145

If an individual does not comply with the mandate under this statute, he or she may be taken to the treatment provider's hospital for examination and treatment. ${ }^{146}$ However, if the individual does not meet the criteria set forth, the hospital may not retain the individual. ${ }^{147}$ The treatment period must last for a minimum of six months, but there may be a petition for renewal or modification. ${ }^{148}$

137. Id.

138. $I d . \S 9.60(\mathrm{c})(5)$.

139. Id. $\S 9.60(\mathrm{c})(6)$.

140. Id. $\S 9.60(\mathrm{c})(7)$.

141. Id. $\S 9.60(\mathrm{j})$.

142. Id. $\S 9.60(\mathrm{e})(1)$.

143. Id.; Scherer, supra note 29, at 391-93.

144. N.Y. MENTAL HYG. LAW $§ 9.60(a)(1)$ (McKinney 2006).

145. Id.

146. Id. $\S 9.60(\mathrm{n})$.

147. Id.

148. $I d . \S 9.60(1)(1)$. 


\section{Weaknesses of the Statute}

Though Kendra's Law is a major step in the right direction toward treatment and de-criminalization of the mentally ill, some weaknesses do exist. The fourth criterion of the statute requiring "a history of noncompliance with treatment for mental illness," ${ }^{149}$ is problematic. Although including the mentally ill individual's medical history may expand upon the traditional civil commitment statutes, it still narrows the population to include only those individuals who have been hospitalized or incarcerated. ${ }^{150}$ Therefore, treatment and medication received through an outpatient plan, such as the one proposed in this article, would be inadmissible in determining whether the individual qualifies for outpatient commitment. ${ }^{151}$

This is a weakness of the statute as it fails to protect a larger population of severely mentally ill individuals who may not have received medication in an inpatient facility (quite possibly due to the lack of availability of a bed in a hospital or the public policy of pursuing outpatient over inpatient treatment) or while incarcerated. $^{152}$

Another weakness in Kendra's Law is that it could require "ccriminalization of the mentally ill' before it will step in to assist severely mentally ill persons." 153 Because the statute requires that the individual be arrested and medicated at least twice within the previous three years, if a patient does not meet both requirements, the courts cannot require treatment. ${ }^{154}$ Unfortunately, many individuals would thus not be required to obtain treatment either because they were not medicated or were not formally charged. ${ }^{155}$ Thus, feasibly the individual on the streets of Indianapolis, who had been arrested eighty-three times in the course of three years, would not qualify for AOT if there was no outside petition, even though he is likely a disturbed individual, if the arrests did not result in medication or formal charges.

Kendra's Law is also deficient in that it omits younger individuals showing signs of a serious mental illness, because of the three or four-year requirement of history resulting in forced medication. ${ }^{156}$ Thus, those indi-

149. Id. § 9.60(c)(4).

150. Scherer, supra note 29 , at $387-88$.

151. Id. at 388.

152. Id.

153. Id. at 390 .

154. Id.

155. Id.

156. Id. 
viduals must keep deteriorating to the point of homelessness, arrest, or rehospitalization after rehospitalization before AOT will take effect. ${ }^{157}$ "Medical research shows, however, that those who begin manifesting signs of a severe mental illness have the greatest chances for recovery if they receive treatment at earlier stages of the illness."158 This stricter requirement, however, does allow for a more narrowly tailored statute, likely in order to comply with constitutional requirements.

\section{B. Other AOT Statutes}

Other states have adopted AOT statutes with various eligibility requirements. ${ }^{159}$ North Carolina was the first state to adopt AOT, though its standard is less stringent than New York's. ${ }^{160}$ Only four requirements must be met: (1) mental illness; (2) ability to live safely in the community with supervision from others; (3) treatment history showing the need for treatment; and (4) lack of insight which would limit the individual's ability to make their own treatment decisions. ${ }^{161}$.

North Carolina has chosen a preventative approach to treatment. One study shows that the preventive approach is extremely successful in terms of treatment compliance for the revolving door patients. ${ }^{162}$ "This standard allows a patient's past history [to] serve[] as evidence of a need for treatment; additionally, this 'past history' component ensures that only those patients who have demonstrated that they cannot, on their own, comply with treatment will be ordered to undergo treatment." $" 163$

Other states have implemented AOT statutes that are similar to North Carolina's, but usually some language differences exist. ${ }^{164}$ For example, Georgia's AOT statute states that the outpatient treatment chosen will "minimize the likelihood of the patient's becoming an inpatient." 165

In Hawaii, the treatment compliance monitoring sets its AOT statute apart from others. ${ }^{166}$ It states that the "patient's status should not go unmonitored, and all efforts should be made to ensure that the patients are taking their medication and complying with other forms of ordered treatment. Only after all efforts have been made to effectuate the patient's compliance should a petition for involuntary commitment be filed."167 Although each

157. See id. at $390-91$.

158. Id. at 391 .

159. Winchell, supra note 19, at 223.

160. See N.C. GEN. STAT. § 122C-263(d) (1999).

161. Id.; Winchell, supra note 19, at 223.

162. Winchell, supra note 19, at 223.

163. Id.

164. Id.

165. Id.

166. Id. at 223-24; see HAW. REV. STAT. § 334-129(c) (1998).

167. Winchell, supra note 19 , at 223-24. 
state employs its own version of AOT statutes, Kendra's Law has generally been considered to produce the most successful results. ${ }^{168}$

\section{Results of AOT Statutes/Studies}

These statutes have proven to be helpful in achieving the goals for which they are intended. ${ }^{169}$ A study of the effectiveness of Kendra's Law in New York has shown that New York's AOT Program has proven to be clearly effective in improving important outcomes for those who receive treatment under it. ${ }^{170}$ Additionally, the negative consequences that had initially been feared were virtually absent. ${ }^{171}$ Those receiving treatment under AOT were more successful in staying in treatment and subsequently being more productive citizens, if they were court-ordered to receive such treatment for six months or more. ${ }^{172}$ Further, improvements were more sustainable among those who continued intensive treatment or were ordered to AOT for longer periods of time. ${ }^{173}$

The 2009 New York study showed that arrests per month before and after AOT, among those who were on treatment, decreased by forty-nine percent. ${ }^{174}$ The adverse conditions in the lives of the mentally ill participants substantially improved. ${ }^{175}$ The study showed a decrease in those who did not adhere to medications, in those who previously tried to harm themselves or to commit suicide, in those who previously tried to harm others, and those who were previously homeless. ${ }^{176}$ Additionally, there was a twenty-one percent decrease in hospitalization (amongst those who were previously hospitalized) of patients who were in AOT for six months, and a thirty-five percent decrease in those who were in AOT for seven to twelve months. ${ }^{177}$ Thus, generally, the 2009 N.Y. Study shows that AOT works to reduce arrests and hospitalizations.

Another report done in New York in 2005, studied the effects of the AOT statutes. ${ }^{178}$ This report also determined Kendra's Law to be a great

168. See generally MARVIn S. Swartz ET AL, NEW York State Assisted OUTPatient TREATMEnt Program Evaluation v-ix (2009), available at http:/www.omh.ny.gov/ omhweb/resources/publications/aot_program_evaluation/report.pdf; N.Y. STATE OFFICE OF MENTAL HEALTH, KeNDRA's LAW: FINAL REPORT ON THE STATUS OF AsSisted OUTPATIENT TREATMENT (2005).

169. SWARTZ ET AL, supra note 168 , at v-ix.

170. Id.

171. Id.

172. Id.

173. Id.

174. Id.

175. Id.

176. Id.

177. Id.

178. N.Y. State OfFice OF MENTAL HEALTh, supra note 168. 
success. ${ }^{179}$ Amongst participants there was over seventy percent reduction in each of the key categories: hospitalization, homelessness, and arrests. ${ }^{180}$ The study also showed a dramatic drop in harmful behavior and a dramatic increase in medication compliance and long-term voluntary treatment compliance. ${ }^{181}$ As a result, the New York Office of Mental Health recommended to the New York legislature that Kendra's Law 2005 sunset date be deleted and to extend Kendra's Law permanently. ${ }^{182}$

A study of the effectiveness of the North Carolina statute on revolving-door patients found that those patients ordered to outpatient commitment were more likely to attend their sessions at the community mental health centers to which they were assigned. ${ }^{183}$ Almost all study participants, ninety-three percent, ordered to outpatient treatment were still in outpatient treatment six months after their hearings, despite the fact that most of the outpatient commitment orders had terminated three months earlier and had not been extended. ${ }^{184}$ Close to half of the patients studied (45.2\%) never missed their appointments without giving an acceptable excuse and rescheduling. ${ }^{185}$ After a second failure to attend, over three fourths $(77.4 \%)$ of the patients attended their scheduled appointments and activities. ${ }^{186}$ "'Given the characteristics of revolving door patients,' the authors of the study noted, 'psychosis, chronicity, dangerousness, multiple hospitalizations, and treatment refusal-these results represent a major accomplishment.", 187

One man who received forced treatment later stated that, "I refused treatment for almost three years after being diagnosed with bipolar disorder, all the while sinking into an increasingly dramatic symptomatic spiral. I was eventually placed in treatment against my 'will.' And because I was-I got better." 188

179. Id.

180. ASSISTED OUTPATIENT TREATMENT LAWS, supra note 21 (showing a $73 \%$ drop in hospitalization, a 76\% drop in homelessness, and a $83 \%$ drop in arrests among the individuals participating in the program).

181. Research on Assisted Outpatient Treatment, Mental Illness Policy OrG., http://mentalillnesspolicy.org/aot/outpatient-commitment-research.html (last visited Sept. 10, 2012) ("[T]he number of individuals exhibiting good adherence to medication increased by 103 percent (from only 34 percent to 69 percent) . . . . AOT also promotes long-term voluntary treatment compliance.").

182. KendRa's LAW: Final REPORT ON THE Status of Assisted OUtPatient TREATMENT, supra note 168.

183. Winchell, supra note 19, at 214.

184. See Virginia Aldige Hiday \& Theresa L. Scheid-Cook, Outpatient Commitment for "Revolving Door" Patients: Compliance and Treatment, 179 J. NERVOUS \& MENTAL DISEASE 83, 86 (1991).

185. Id. at 87 .

186. Id. 87).

187. Winchell, supra note 19, at 215 (quoting Hiday \& Scheid-Cook, supra note 184, at

188. Jonathan Stanley, Personal Results, Treatment Advocacy CTR., http://www. 


\section{Argument against AOT Statutes: Constitutionality}

The main legal argument against AOT statutes is that they affect a person's right to choose whether to be treated and thus challenges the constitutionality of such statutes. However, while the constitutionality issues regarding AOT statutes have not yet been heard by the U.S. Supreme Court, New York has upheld AOT statutes and Kendra's Law as constitutional. ${ }^{189}$ In the landmark decision of In re K.L., a man with schizoaffective disorder who did not regularly take his prescribed medications challenged the constitutionality of Kendra's Law on the grounds that it violated his equal protection rights because the statute did not require a threshold finding of his incapacity to make his own treatment decisions. ${ }^{190}$ However, the New York Court of Appeals found that such a requirement was unnecessary, the mentally ill have never been deemed a protected class, and therefore the statute did not violate his equal protection rights. ${ }^{191}$ Rational basis scrutiny is likely to apply to such claims because of the lack of protected class status if there are findings of discrimination. There are often "legitimate (if not compelling or substantial) reasons why individuals with relevantly different mental illness should receive differing forms of psychiatric treatment." 192

As to the issues of due process, the court again found the statute to be constitutional because it was narrowly tailored and served a legitimate state interest. ${ }^{193}$ In essence, Kendra's Law was achieving a compelling state interest under both police and parens patriae powers and was tailored narrowly enough so as to overcome constitutional claims. ${ }^{194}$ Thus, Kendra's Law was upheld on both the procedural and substantive due process grounds for which it was challenged. ${ }^{195}$

With respect to the right to refuse psychiatric medication, the United States Supreme Court has identified the existence of a right to refuse medication, but only in inpatient hospitalization and incarceration contexts. ${ }^{196}$ Further, the Court need not apply strict scrutiny because it has never defined the right as fundamental. ${ }^{197}$ There is room for a state to strike its own balance between the state's interest in medicating a patient in a controlled setting, such as a hospital, and a person's right to refuse medication. ${ }^{198}$

treatmentadvoca-

cycenter.org/index.php?option=com_content\&task=view\&id=19\&Itemid=48 (last visited May 9, 2012).

189. In re K.L., 806 N.E.2d 480, 486-87 (N.Y. 2004).

190. Id. at $485-86$.

191. City of Cleburne v. Cleburne Living Ctr., 473 U.S. 432, 440 (1985).

192. Scherer, supra note 29, at 406.

193. In re K.L., 806 N.E.2d. at $486-87$.

194. Id.; Scherer, supra note 29, at 401-02.

195. In re K.L., 806 N.E.2d. at 486-87.

196. See Washington v. Harper, 494 U.S. 210, 229 (1990); Mills v. Rogers, 457 U.S. 291, 299 (1982).

197. Scherer, supra note 29 , at $401-02$.

198. Id. 
Additionally, legislation supports the notion that AOT statutes are in place in order to prevent incarceration and repeated inpatient hospitalization. ${ }^{199}$ So why there would be a higher standard for outpatient statutes, which are less restrictive on patients' rights, is unknown, and indeed unlikely. ${ }^{200}$ Therefore, while the U.S. Supreme Court has not yet reviewed AOT statutes and a patient's right to refuse medication in that context, the standard of review is likely to be deferential to the statute. ${ }^{201}$ Thus, while there have been no Supreme Court rulings regarding AOT statutes as of yet, it is likely that they would be upheld as constitutional.

\section{INDIANA'S AOT STATUTE}

\section{A. Indiana Statute}

Like other states, Indiana has a series of statutes that address AOT. ${ }^{202}$ Under Indiana law, in order to receive AOT, an individual must satisfy four criteria. They must be.(1) "[m]entally ill and either dangerous or gravely disabled,",203 (2) "[1]ikely to benefit from an outpatient therapy program that is designed to decrease the individual's dangerousness or disability;"204 (3) not likely be either "dangerous or gravely disabled if the individual complies with the therapy program;", ${ }^{205}$ (4) and "[r]ecommended for an outpatient therapy program by the individual's examining physician." 206 Unfortunately, however, the statute is rarely used by courts for involuntary treatment, except to transition some individuals from inpatient commitment to outpatient commitment. ${ }^{207}$

\section{B. Weaknesses of Indiana's Statute}

This statute has many weaknesses which render the use of AOT through a court order to be ineffective means of treatment. The "dangerous or gravely disabled" language is clearly too high of a standard to meet for outpatient treatment, there is no standard of proof in the language, the statute gives no indication of whether 3rd party petitions are accepted, there is no time commitment required for treatment, there are no definitions of the terms, and most importantly, there are no guarantees of outpatient treatment

199. Id. at 405 .

200. Id.

201. Id.

202. IND. CODE § 12-26-14-1 (2010).

203. Id.

204. Id.

205. Id.

206. Id.

207. FLYNN \& ESPOSITO, supra note 26. 
placement. $^{208}$ One of the biggest challenges Indiana will face if the statute is not changed is that there is no system in place to monitor the outpatient treatment program and, more importantly, compliance with it. ${ }^{209}$ Without such a system, many seriously mentally ill individuals who lack insight into their disorder will not stay on the treatment course and will stop taking their medications, thus perpetuating the cycle. ${ }^{210}$ The lack of a strong AOT statute in Indiana law is unacceptable.

\section{Dangerous or Gravely Disabled}

The strict standard of "dangerous or gravely disabled" makes such a statute nearly indistinguishable from the inpatient civil commitment statutes, and thus a very difficult barrier when petitioning for an individual who may otherwise need AOT. ${ }^{211}$ This standard is difficult to meet when trying to get an individual civilly committed. ${ }^{212}$ When the individual does not need civil commitment, but could survive in the community with outpatient treatment, this is an even harder burden to establish.

In 1999, the Department of Justice reported that as much as 16 percent of the population of state jails and prisons, more than 260,000 individuals, suffer from severe mental illnesses. While the vast majority of these individuals are arrested for non-violent crimes, it is inevitable that waiting for someone to become dangerous will culminate in violent episodes. ${ }^{213}$

Such violence is insupportable when there is a better solution at hand.

\section{No Standard of Proof}

There is also no standard of proof that the state must meet in order to satisfy the criteria of "dangerous or gravely disabled." 14 With no standard of proof in the language, it is possible that a judgment could be made based on any amount of evidence presented. Such lax standards with which to force someone into involuntary treatment defy our society's justice system: they fly in the face of the constitutional guarantees against random judg-

208. IND. CODE § 12-26-14-1 (2010).

209. Interview with NAMI Executive Board, in Indianapolis, Ind. (Feb. 12, 2011) (on file with author).

210. Id.

211. See Scherer, supra note 29 , at 379-80.

212. Id.

213. Torrey \& Zdanowicz, supra note 35 .

214. IND. CODE § 12-26-14-1 (2010). 
ments and unchecked police power.

\section{Lack of 3rd Party Petition Ability}

The Indiana statute does not give 3 rd parties an ability to petition the court to have an individual evaluated for AOT. ${ }^{215}$ This means that only individuals who have committed a crime and are brought before a judge are eligible for this type of treatment. Meanwhile, others who are on the street or elsewhere in need of treatment, are ineligible. Family members will be left helpless and frustrated with the system. This is not how Indiana should treat its citizens.

\section{No Mandated Time Commitment}

Under the statute as it currently stands, no minimum period of time that a patient who is mandated to AOT must undergo the treatment exists. ${ }^{216}$ Though the needed period of time will vary in different cases, there must be some minimal starting-off point. Without that, and without guidance as to how much time must be given for the treatment to start working, it is possible that a mentally ill individual could go to treatment for only one week, or even one day for that matter, and still fulfill the requirements set out by the statute. This, however, is not nearly enough time for such treatment and is an unacceptable standard.

\section{No Definitions for the Terms}

One major flaw in the statute is the lack of definitions of terms. ${ }^{217}$ This makes it very difficult to interpret and apply the statute. For instance, while the terms "dangerous" and "gravely disabled" may have been given meaning in other statutes for civil commitment, their meanings here could be very different. The difference is in the liberty interest that is restricted. One's liberty is much more greatly restricted in an inpatient hospital setting, as with inpatient commitment, than it is when being medically monitored outside in the free world, as in an outpatient setting. However, these terms, and others like them in the statute, could also indicate an entirely different meaning than what is given to them in civil commitment statutes. It is unclear from the language as it stands of what is truly meant and how the court should interpret the terms. 


\section{No Guarantees of Outpatient Program Placement}

Finally, as the statute is currently written and applied, there are no guarantees of placement into an outpatient program, even if the court does find that the individual qualifies under the statute. ${ }^{218}$ Without such guarantees by the state, there will likely not be enough physicians or other medical professionals on staff to assist these individuals, and they will fall by the wayside as in the past. Even with Assertive Community Treatment (ACT) teams to do the more hands-on work with the individual, there would need to be a supervising psychiatrist that the court would look to in its assessment. ${ }^{219}$ As it is, the state is consistently cutting the budget of mental health services. ${ }^{220}$ Without guarantees that someone will be treated or placed in the program, courts will be unlikely to use such statutes.

\section{Results of Indiana's Statutes}

Indeed, as the Indiana statutes are currently written, AOT is rarely used by the court in lieu of imprisonment or a simple release without treatment after arrest for a small misdemeanor. ${ }^{221}$ That is not to say that Indiana is doing nothing to help the mentally ill. There are several programs instituted to help for those who voluntarily would seek admission to an outpatient program, such as PAIR; or for Crisis Intervention Training (CIT) officers, who are being trained on how to properly respond to situations involving the mentally ill, in lieu of the standard arrest. ${ }^{222}$ However, in Indiana, there are approximately 250,000 Hoosiers with a serious mental illness. ${ }^{223}$ Given the lack of insight associated with such conditions, most of these people, left untreated, will end up homeless or in jail. Additionally, at any given time the Indiana Department of Corrections holds over 4000 people with a serious mental illness and only a very small percentage of them are on any kind of psychiatric medication. ${ }^{224}$ Thus, in order to fight for the rights of the mentally ill to a better quality of life, the AOT statutes must be amended, if not completely re-done.

218. Id.

219. Parker, supra note 27.

220. Id. (stating that the Division of Mental Health and Addiction (DMHA) is currently in the process of transitioning 1200 state hospital beds to 850).

221. FLYNN \& ESPOSITO, supra note 26.

222. Collins, supra note 28.

223. Parker, supra note 27.

224. Id. (only fifteen percent of those seriously mentally ill inmates in the Indiana DOC are on medication). 


\section{REVISED AOT STATUTE PROPOSAL FOR INDIANA}

\section{A. Kendra's Law with Modifications}

The introduction to the Model Law for Assisted Treatment states that: "Perhaps the single most important reform needed to prevent the need for repeated hospitalization and to prevent the consequences of non-treatment is to encourage the use of assisted outpatient treatment.",225 Indiana thus needs to reform its AOT statutes in order to accommodate for the increasing need for treatment of its seriously mentally ill citizens.

One important reform that should be administered in the statute is that it should be proactive. Currently, the AOT statutes in place are fairly retroactive in nature in that they are applied to individuals who have gone through the system repeatedly, and have been in and out of jails or homeless for a long period of time. The court should take a proactive approach and include a broader class of people who can petition the court as a 3rd party. The court should also order psychological evaluations on individuals who exhibit signs of a severe mental illness while in jail. With these reforms the revolving door may be less active and incidences of violence, homelessness, and unnecessary arrests would go down, and quality of life for certain individuals would go up.

Included in this reform should be a discharge/treatment plan for anyone that is seriously mentally ill and is discharged from an outpatient program, a long hospitalization, or prison or jail in order to reintegrate them into society. Often, a mentally ill individual just released from jail or prison will be set free without any type of re-integration or treatment plan. ${ }^{226}$ Further, if the person was receiving medication in jail or prison, there is a lapse between the time when they are released and the time when they may reapply for Medicare benefits in order to continue treatment. ${ }^{227}$ If things run very smoothly on all sides, even then it would take a minimum of ninety days for someone to get approved for their benefits again, yet so often things do not run smoothly with administrative agencies. ${ }^{228}$ As such, it would take much longer than three months in order to receive treatment. ${ }^{229}$

225. Torrey \& Zdanowicz, supra note 35.

226. Interview with Trina Randall, Public Information Officer, New Castle Correctional Facility (Feb. 3, 2011).

227. Interview with NAMI Executive Board, supra note 209; Collins, supra note 28.

228. MiCHAEL W. KEMPF, NAMI INDIANA, MENTAL IllNESS AND THE CRIMINAL JUSTICE SYSTEM IN INDIANA 24 (2008), available at http://www.nami.org/Content/Microsites169/ NAMI_Indiana/Home156/Resources87/Kempf_Report_6_13_2008.pdf ("A case manager for Midtown Mental Health indicates that in a perfect world, it takes a minimum of 90 days to get someone approved and we do not live in a perfect world. Clients who have been incarcerated often do not have the identification and other requirement to begin the application process.").

229. Id. 
This is unacceptable. A re-integration or immediate treatment plan needs to be available to the individual upon release, so no reversion back to the anosognosia symptom occurs, and patients are given them a chance to be a productive citizen with a higher quality of life than they would have without treatment.

A treatment plan should include but not be limited to: "suggested medication; individual or group therapy; day or partial day programming activities; services and training, including educational and vocational activities; residential supervision; intensive case management services; and living arrangements." 230 However, the housing to be arranged needs to be less strict about rule adherence, so that it is easier for a mentally ill individual to comply, without the constant threat of being evicted for a minor infraction. $^{23}$

In order to help more homeless or runaways, the criteria for someone being able to petition the court for AOT should also be lessened to anyone with a good faith belief that AOT is absolutely necessary. ${ }^{232}$ There should be a criminal penalty for false petition in order to deter this provision from being used in the wrong way (vengefully or without a true motive of helping the person). ${ }^{233}$ According to the Model Law for Assisted Treatment, the language should read: "It shall be a crime to knowingly file, or cause to be filed, a petition that contains a false material statement or information.",234

In order to account for this shift in the mentally ill person's civil rights, there should be further constitutional rights afforded to him when he is brought before the court. Included in the statute should be a "formal grievance procedure whereby patients can bring complaints to the facility's medical director and, if necessary, to the Psychiatric Treatment Board."235 More significantly, there should be a provision to safeguard the bodily integrity of the mentally ill individual, i.e. an examination of the individual for medication side effects every thirty days by either a psychiatrist or physician. $^{236}$

Also needed is a provision stating that the treatment must be the least restrictive available that will meet the patient's clinical needs. The patient

230. Jonathan Stanley, Important Aspects of the Model Law, in ModEL LAW FOR ASSISTED TREATMENT $\S 14.3$ (2000), available at http://www.treatmentadvocacycenter.org/ GeneralResources/index.php?option=com_content\&task=view\&id=49\&Itemid=78.

231. KEMPF, supra note 228 , at 23 ("Group homes and other housing arrangements have attempted to meet the needs of this population, but often, the administrative rules governing acceptance into a group home or rules governing the behavior of the residents are applied so strictly that the individual with a mental illness is turned out on the street if the rules are broken.").

232. Stanley, supra note $230, \S 5.1$.

233. Id. § 5.6.

234. Id.

235. Stanley, supra note 188.

236. Id. 
should be placed on either intensive case management or assertive community treatment ("ACT") if available. If a supervising physician approves, and it is appropriate, the individual may be able to fulfill his or her AOT obligations at his or her own residence, or at a treatment center or group home, whichever the patient chooses. ${ }^{237}$ If they fail to comply with the AOT program, the reprimand should not be jail, but more appearances before the judge, to ensure they will comply. The individuals who comply with treatment should be rewarded by progressively fewer court appearanc-: es and less supervision, much like the PAIR program. ${ }^{238}$

Finally, it would be important to move the standard of proof required to show that the individual qualifies to the beginning of the statute, instead of being mixed with other language in the middle. This will make it easier for the court to determine whether the standard has been met and what kind of evidence is necessary.

\section{FUNDING}

Funding is a crucial and often overlooked question to address when discussing implementation or revision of AOT statutes. Funding is a major problem in our mental health system for providing the severely mentally ill assisted outpatient treatment. ${ }^{239}$ A majority of the AOT funding goes to treatment of individuals in inpatient programs or hospitals. ${ }^{240}$ As a result, the essential resources needed to obtain the proper number of clinicians and other psychology-related personnel required to move such a program forward and treat the individuals on an outpatient basis are lacking. ${ }^{241}$ Thus, funding becomes an issue of great importance.

"It is a mistake to think that money is saved overall by not treating individuals with severe psychiatric disorders." 242 Those left untreated cost the state and federal government much more money through their repeated incarcerations. $^{243}$ The total cost in jails and prisons alone is estimated by the Department of Corrections to be over $\$ 15$ billion. ${ }^{244}$ Each year, untreated mental illness costs the United States $\$ 100$ billion or more because of unemployment, homelessness, inappropriate incarceration, and sui-

237. Stanley, supra note $230, \S 7.5-7.6$.

238. Collins, supra note 28.

239. Interview with NAMI Executive Board, supra note 209.

240. Id.

241. Id.

242. Treatment Advocacy Ctr., Consequences of Non-treatment, http://www. treatmentadvoca-

cycenter.org/index.php?option $=$ com_content\&task=view\&id=1384\&Itemid=221 (last visited Mar. 26, 2012).

243. Id.

244. Id. 
cide. $^{245}$ More importantly, "[t]he largest intangible cost, of course, is the effect on the family."246 However, there are ways to reduce these costs and even to obtain funding from the government in order to subsidize AOT programs.

\section{A. Benefits of AOT: Reduction in Hospital Costs}

A usable AOT statute in Indiana would lead to a reduction in hospitalization costs. $^{247}$

Inpatient care is the most expensive form of mental health treatment. In the past ten years, mental health care costs have risen in response to higher psychiatrist's fees and prescription costs. Patients caught in the revolving door, under current statutes, typically end up spending sporadic periods of time in a mental hospital, and this time quickly adds up. ${ }^{248}$

Studies show that people who are treated with AOT spend less time in hospitals and prisons, thus reducing costs of accommodating them. ${ }^{249}$ Therefore, while funding may be an issue initially, long term it will be offset by other costs no longer present.

\section{B. Funding Through Medicaid or Taxes}

Funding may also be found by applying to Medicaid for reimbursement of psychiatric services. ${ }^{250}$ Medicaid provides some funding to hospitals and individuals with a serious mental illness who are in need of treatment/medication. ${ }^{251}$ States should receive increased Medicaid contributions for any psychiatric or medical services provided through AOT as it replaces its inpatient hospitalization services counterpart. ${ }^{252}$ In 2001 , the New Freedom Initiative was launched to "promote full access to community life for people with disabilities." 253 This initiative included mental health

245. NAT'L ALLIANCE ON MENTAL IllNESS IND., supra note 45.

246. TREATMENT ADVOCACY CTR., supra note 242.

247. Winchell, supra note 19, at 226.

248. Id.

249. Id. at $227-28$.

250. Kress, supra note 60, at 1352.

251. Id.

252. Id. (citing 42 U.S.C. § 1396(a)(xi)(1) (1999)).

253. U.S. Dep't Health and Human Servs., Substance Abuse \& Mental Health Servs. Admin., Transforming Mental Health Care IN America (2010), http://www. samhsa.gov/federalactionagenda/NFC_execsum.aspx. 
care $^{254}$ and builds on the Americans with Disabilities Act, emphasizing the "requirement that services be provided to the maximum practicable extent within the community rather than in institutional settings." ly, a $1 \%$ tax increase on those who earn over $\$ 1$ million would generate a great deal of revenue, like in California, where the Mental Health Services Act provided funding for mental health programs. ${ }^{256}$ While this Act was implemented only for treatment on a voluntary basis, ${ }^{257}$ there is no reason why the revenue could not help support both voluntary and involuntary treatment in Indiana.

\section{CONCLUSION}

[Many individuals with a serious mental illnes] are unaware they are sick and should be required by law to receive assisted outpatient treatment, including medication and counseling, as is the case in New York under Kendra's Law. If they do not comply with the court-ordered treatment plan, they can and should be involuntarily admitted to a hospital .... Ultimately, it is important to hold state officials responsible for not providing sufficient resources to treat those who suffer from serious mental illnesses .... State governments have been very effective in emptying the hospitals in an effort to save money but remarkably ineffective in providing treatment for seriously mentally ill individuals living in the community. ${ }^{258}$

If the state of Arizona had a more effective AOT statue, perhaps the tragedy perpetrated by Jared Loughner could have been avoided. By mandating treatment when school and police officials recognize the signs of mental illness, future tragedies may be prevented. If so, the lives of not only the victims in the shooting, but also of the unwitting perpetrators, may be saved. It is an important function of the government to not only care for individuals the state deems worthy or less burdensome, but also to care for those individuals that are left behind by the system and need greater care. All citizens deserve protection of the state, yet some are discarded by that same body who long ago promised to afford everyone the same opportunities, rights and protections. States must now step up and do their part in

256. Scherer, supra note 29 , at $426-27$.

257. Id. at 427.

258. Torrey, supra note 2. 
providing preventative treatment for seriously mentally ill individuals. This goal can be achieved through AOT. 
